\title{
Evaluation of the Successfulness of a Green Program Through Customer Perceived Quality, Brand Image, and Customer Satisfaction: A Case Study at Surabaya Plaza Hotel
}

\author{
Marsella Yeanette Hatane \\ PT. Surabaya Panel Lestari, Olympic Furniture Group \\ Jl. Kapten Darmo Sugondo Gresik 61124 \\ Email: hatanemarsella@yahoo.com \\ Adinda Yosari \\ PT Boga Food Service \\ Grand Wijaya Centre Blok E18-E19 Jakarta 12160 \\ Felicia Christiana Hendautomo \\ Surabaya Plaza Hotel \\ Jl. Pemuda 31-37 Surabaya 60271
}

\begin{abstract}
Every company tried to build the brand image by doing a green program. This research aimed to see the impacts of the implementation of a green program at Surabaya Plaza Hotel, Surabaya. 230 hotel customers were randomly chosen as the respondents and analyzed through descriptive and SEM analysis. It could be seen that technical quality brings insignificant negative impacts towards customer satisfaction. Meanwhile, functional quality and brand image bring a significant positive impact toward customer satisfaction. Besides that, technical quality and functional quality bring a significant positive effect indirectly toward customer satisfaction through brand image as mediating.
\end{abstract}

Keywords: Green Program, Brand Image, Customer Perceived Quality, Customer Satisfaction, Technical Quality, Functional Quality

\begin{abstract}
Abstrak
Setiap perusahaan berusaha membangun citra merek dengan menjalankan green program. Penelitian dilakukan untuk melihat dampak penerapan green program Hotel Surabaya Plaza, Surabaya. Sebanyak 230 konsumen hotel dipilih sebagai sampel dan dianalisis dengan analisis deskriptif dan SEM. Terlihat bahwa kualitas teknikal berpengaruh negatif tidak signifikan, terhadap kepuasan konsumen, sedangkan kualitas fungsional dan citra merek berpengaruh positif secara signifikan terhadap kepuasan konsumen. Selain itu kualitas teknikal dan kualitas fungsional berpengaruh positif signifikan secara tidak langsung terhadap kepuasan konsumen melalui variabel citra merek sebagai mediasi.
\end{abstract}

Kata Kunci: Green Program, Citra Merk, Kesan Kualitas Konsumen, Kepuasan Konsumen, Kualitas Teknikal, Kualitas Fungsional

\section{INTRODUCTION}

One of the most striking phenomenon in this era of globalization is the growth in industry and technology. Besides making human life easier and simpler, there is another side of this globalization era which gives the bad impact for nature. One of the consequences is the phenomenon of global warming. With the existence of these natural phenomena, more reactions come from people who are concerned with today's world condition. This can be seen from the results of surveys that have been held in various regions, including in Indonesia on community care to the environment conducted by AC Nielsen as one of the pollsters. Judging from the survey, the Indonesian consumers actually have big concern to some environmental issues.

Go green campaign also had an impact in the areas of government. Even Surabaya city is also involved in go green campaign. This can be seen from Peraturan Daerah (Perda) on Non-Smoking Area and Limited Smoking Area, which has started from Octo- 
ber 20, 2009. Nowadays, the attention to environmental aspects have grown bigger. It is reflected in the increasing demand for eco-labeling, green marketing, and environmental movements. Green marketing is any activity that designs services and facilities or the satisfaction of human needs and desires, with no impact on the natural environment (Hollensen, 2007).

Awareness also arises from the services companies to take part in the operations of applying go green company. Without exception, the hotel businesses also apply green marketing in the various forms of green programs in providing services and indirectly encourage consumers to go green living as well. Looking at these phenomena, Surabaya Plaza Hotel Management helped to develop the concept of "Green Hotel" as its concern in supporting the preservation and improvement of the current environmental condition deteriorated. Green programs which are implemented at Surabaya Plaza Hotel are smokefree areas, saving water and electricity in hotel operations, as well as waste management. In the beginning of August 2010, SPH has won a national award "Best Green Hotels Indonesia 2010" for environmentally green policy, such as implementing a non-smoking hotel.

Based on this phenomenon, this research will be carried out in order to relate the application of customer perceived quality, brand image, and customer satisfaction at Surabaya Plaza Hotel that implement Green Program.

\section{LITERATURE REVIEW}

A hotel is a type of accommodation that employs some or all of the buildings to provide lodging, food and beverages, as well as other support services for commercially-managed (Sulastiyono, 1999). According to him, hotel classification cannot be separated from customer's needs and unique characteristics of tourists. Based on that, hotels can be divided into Business Hotel, Residential Hotel, Resort Hotel, Motel (Motor Hotel). Green hotel is a friendly environment lodging property where the hotel implements friendly environment programs, such as saving water and energy, waste management, and cost savings to help protect our planet. According to Kasali (2009), green program is a program that refers to the act of someone who consciously takes action to prevent the harmful effects on the environment through consumer habits, behavior, and lifestyle.

According to Kotler et al. (2003), consumer behavior is the study which studies how individuals, groups, and organizations select, buy, use, and dispose of products, services, ideas, or experiences to satisfy needs and desires. Customer perceived quality is the consumer evaluation of the quality of services delivered (Gronroos, 2000). According to him, customer perceived quality have been divided based on two dimensions, technical quality and functional quality. Technical quality is concerned with what is provided by companies to their customers. Included in it is the ability of operating the machine, the knowledge of employees in the services offered and more. Functional quality is related to how a service provided to customers. Included in it is the accessibility of the service to the customer, the physical appearance of the office, long-term customer relations, internal relations within the company, and attitudes, service of the employee or service provider. Professionalism and skills dimensions are included in technical quality. Attitudes and behavior, accessibility and flexibility, reliability and trustworthiness, service recovery, reputation, and credibility dimensions are included in functional quality.

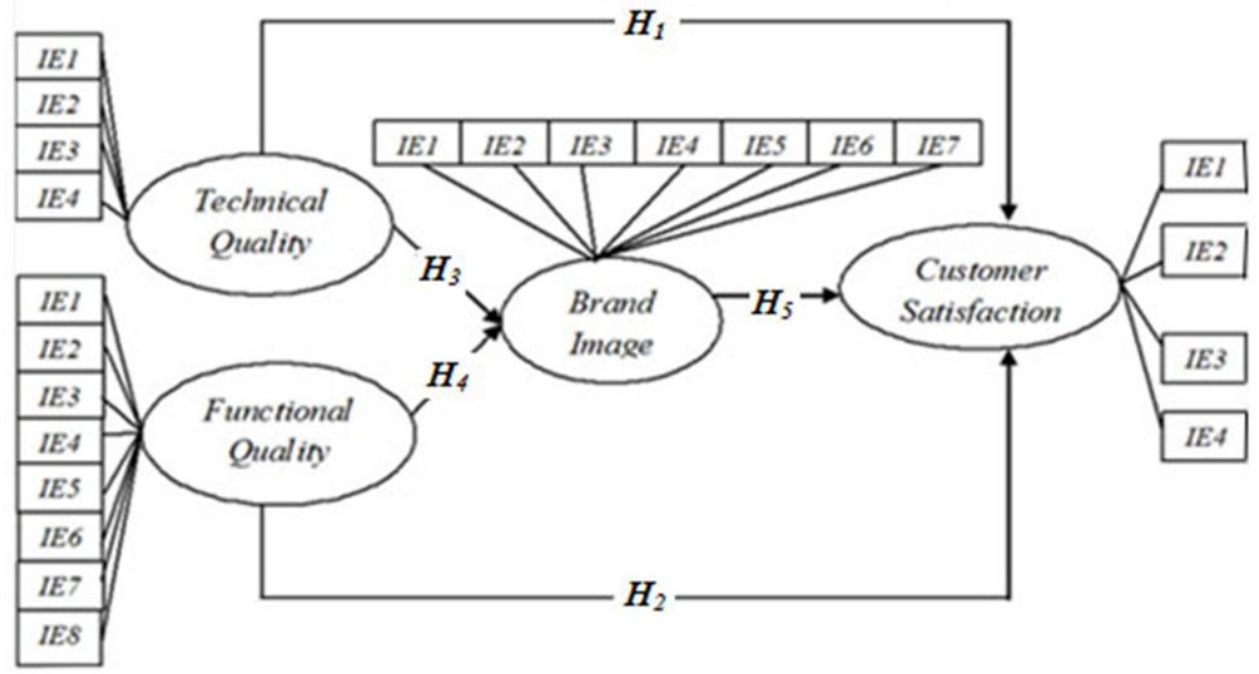

Figure 1. Conceptual Framework 
Based on Kotler (1997), brand is a name, term, symbol or special design or some combination of elements that are designed to identify the goods or services offered by the seller. He defines brand image as asset of beliefs, ideas, and the impression which is owned by someone of a brand. There are three factors for measuring brand image, namely: favorability of brand association, strength of brand association, uniqueness of brand association. Kotler (1997) in general, stated that consumer satisfaction is a feeling level obtained after the consumers do/enjoy something.

\section{Conceptual Framework and Hypothesis}

Based from the diagram of conceptual framework above, hence, the following hypothesis is proposed:

$\boldsymbol{H}_{1}$ : Technical quality of customer perceived quality directly affected customer satisfaction

Through the study of Kotler et al. (2003), it is shown that perceived quality variables were observed to provide the greatest contribution to the formation of customer satisfaction. The influence of service quality to customer satisfaction is described by them as follows: "Higher levels of quality (product or service) result in greater customer satisfaction." This statement indicates that the high service quality will make the greater amount of satisfaction customer. Furthermore the skill that the staffs have in giving the service to the guest does reflect in the satisfaction of the guest, since the guest expects the staff to be professional in giving the service.

$\boldsymbol{H}_{2}$ : Functional quality of customer perceived quality directly affected customer satisfaction

Zeithaml et al. (2006) stated that, "Satisfaction is more inclusive: It is influenced by perception of service quality." It means that, existence of customer satisfaction is influenced by customer perceptions of service quality. Thus it can be said that service quality has a positive influence on customer satisfaction. The study of Kotler et al. (2003) shows that customer satisfaction is influenced by the core quality, quality of relationships (relational quality) and perceived quality. Furthermore, functional quality is about the process while the service is given to the guest by the staff. In the end, the customer satisfaction can be achieved due to the process of the service given.

$\boldsymbol{H}_{3}$ : Technical quality of customer perceived quality directly affected brand image

Kotler (1997) stated that technical quality of perceived quality is linked to and often drives other aspects of how a brand is perceived. He states in his book if the perceived quality increases, the image of the brand or the brand will also increase. Therefore, it is important for companies to provide good service for guests in any circumstances. It is because the professionalism of the hotel staff may greatly affect the image of the hotel. If the staff does not have the skill and an adequate understanding of his working area and about the hotel where he works in particular, the image of the hotel would also be affected.

$\boldsymbol{H}_{4}$ : Functional quality of customer perceived quality

Kotler (1997) stated that functional quality of perceived quality is linked to and often drives other aspects of how a brand is perceived. He states in his book if the perceived quality in creases, the image of the brand or the brand will also increase. Therefore, it is important for companies to provide good service to guests in any circumstances. The staff of a hotel is the representative of the hotel itself. Because the staff is the one that deal with and provide services to all guests staying at the hotel. Thus, this functional variables very influential, because it is about process variables related quality or service quality associated with the process of service creation. While the staff provides services to the guests, at the same time the hotel image formation occurs in the minds of the guests about the hotel.

$\boldsymbol{H}_{5}$ : Brand image is as an intervening variable between customer perceived quality and customer satisfaction

Functional quality perceived by guests staying at the hotel then in turn affects the image of consumers towards the hotel. The image that is formed and embedded in the minds of consumers is what ultimately affects the level of customer satisfaction in a hotel. Brand image is an important determinant of customer satisfaction, there is a positive relationship between brand image and customer satisfaction (Chang \& Tu, 2005; Martenson, 2007). So, that is why the quality of the staff, either the technical quality or the functional quality do have a great effect to the brand image of the company. In connection to the brand image that is formed, it could ultimately affect the consumer satisfaction for the hotel services (Chen, 2010).

\section{RESEARCH METHODOLOGY}

\section{Population and Sampling Design}

This research used causal quantitative to draw conclusions by using hypothesis testing. This research will explore among the customer perceived quality, brand image, and customer satisfaction at Surabaya Plaza Hotel that implements Green Program. 
The population in this research were all the Surabaya Plaza Hotel guests who are 25 years to 65 years old considering their behavior and state of mind. This research used non-probability sampling due to infinite population. There are 230 respondents who participate as the samples in this research.

\section{Data Collecting Procedures and Method}

\section{Stage 1. Building a Questionnaires}

In this research, field research will be conducted to obtain a set of data which, according Supranto (2006). Acquisition of data is obtained through questionnaires in the sample. In this case, the authors conducted there search by interacting directly with the respondents. Respondents were asked to response 12 questions about customer perceived quality including its manifest variables, and seven questions about brand image including its manifest variables, and four questions about customer satisfaction including its manifest variables. Responses are scored using a 5point scale: strongly disagree $=1$, disagree $=2$, neutral $=3$, agree $=4$, strongly agree $=5$.

\section{Stage 2. Quantitative Study for Customer Perceived Quality, Brand Image, and Customer Satisfaction}

A pilot test using a sample of 40 respondents was conducted and it indicated that every question in the questionnaire is valid and reliable, tested using Statistical Packet for Social Science (SPSS) program. A pilot test has been spread out at Surabaya Plaza Hotel area. The second stage of the study involved consumers survey to gain insight about the customer perceived quality of Surabaya Plaza Hotel that implements green program toward the customer satisfaction with brand image as an intervening variable. This study used 230 respondents to response the survey.

\section{Operational Definition of Variables}

There are three kinds of operational variables used in this model, they are: a dependent variable, independent variable, and intervening variable.

The dependent variable in this model is the customer satisfaction. This variable is affected by the customer perceived quality and brand image. The satisfaction of the services given and also the satisfaction of the facility are the manifest variables for the customer satisfaction.

The independent variable in this model is customer perceived quality. This model use professionalism, attitude, flexibility, service, credibility, and reputation are the manifest variables for the customer perceived quality.
Intervening variable in this model is the brand image. This variable mediates between the dependent variable and independent variable. The brand image has three manifest variables, they are: favorability, strength, and uniqueness.

\section{Data Analysis Technique}

1. Validity and Reliability Testing

This research used Statistical Packet for Social Science (SPSS) program to measure the questionnaires' validity and reliability. Validity is to test whet her theme asured test is in match with what the authors want tome asure. Reliability test is the extent towhich the results of testing is reliable.

2. Descriptive Data Analysis

It is used to describe data characteristics in both text and diagrams. The descriptive statistics can also be done to find the strength of the relationship between variables.

3. Cross Tabulation Analysis

Cross tabulation analysis is a basic analysis for describing the relationship between categorical variables (nominal or ordinal).

4. Top Two Boxes Bottom Two Boxes Analysis The analysis of the Top Two Boxes and Bottom Two Boxes are methods that combines the percentage of respondents in a Likert scale. The analysis of Bottom Two Boxes and Top Two Boxes are used to determine the ratio between the number of bottom option (score 1,2), the scale of strongly disagree and disagree with the top option (score of 4,5 ) the scale of agree and strongly agree.

5. Structural Equation Modeling Analysis

Structural Equation Modeling (SEM) is a family of statistical models that seeks to explain the relationships among multiple variables (Arbuckle, 1997). So, by using SEM, the authors can study the structural relationships that are expressed by a set of equations, which is similar to a set of multiple regression equations.

\section{DATA ANALYSIS}

\section{Respondent's Profile Description}

There are 230 respondents who participate in this research. Most of the respondents in this research were males (142 respondents), aged between 36-45 years old (85 respondents), entrepreneurs (98 respondents), staying at Surabaya Plaza Hotel less than two times in the last 6 months (115 respondents), most of the respondents have monthly incomes more than Rp 6.000.000,00 (89 respondents). 


\section{Validity and Reliability Testing}

This research used Statistical Packet Social Science (SPSS) program to measure the questionnaire validity. The result (which is applied in the reference) shown that all the question corrected item total correlation were more than or equal 0.300 . Besides, the Cronbach's Alpha value were more than or equal to 0.600 . Therefore, all the question in the questionnaire were valid and reliable and could be used for further research.

\section{Research Description}

This research used cross tabulation analysis. Cross tabulation analysis is the basic analysis for describing the relationships between categorical variables (nominal or ordinal). In this research the variables are all cross tabulated with the gender of the respondents. Because the authors want to find the differences between the perspective of male and female about the customer perceived quality, brand image, and also customer satisfaction. Based on the result of this research, the female respondents are relatively more concern about the cleanliness of the hotel and also the facility that is provided by the hotel for the guests. Whereas, the male respondents are relatively easier to be satisfied with the service given by the service provider than the female ones. This is because the females tend to be more sensitive toward the attitude and behavior of the service provider during their stay at Surabaya Plaza Hotel.

This research used the two boxes approaches. The bottom two boxes approach accumulates two bottom answers in 5-point scale, they were strongly disagree $=1$ and disagree $=2$. On the contrary, top two boxes approach accumulates two top answers in 5 -point scale, they were agree $=4$ and strongly agree $=5$.

The highest degree of the customer perceived quality in professionalism dimension was the knowledge that the hotel staffs give to the guest from the reused linen sign. The highest degree of the customer perceived quality in attitude dimension was the hospitality of the staff toward the guests in giving the service while they were staying in the hotel. The highest degree of the customer perceived quality in flexibility dimension was the flexibility that Surabaya Plaza Hotel has regarding the non-smoking area by preparing a smoking room only for smoking guests. The highest degree of the customer perceived quality in service dimension was the cleanliness of the air in the Surabaya Plaza Hotel that is implementing a nonsmoking are in the Hotel area to minimize the smokes from cigarettes. The highest degree of the customer perceived quality in credibility and reputation dimension was the implementation of green program that matches with Surabaya Plaza Hotel commitment toward the nature.

The highest degree of the brand image in favorability dimension was the concept of Surabaya Plaza Hotel which is very interesting because it is environmentally friendly. The highest degree of the brand image in strength dimension was the strong commitment that Surabaya Plaza Hotel has toward nature. The highest degree of the brand image in uniqueness dimension was Surabaya Plaza Hotel is the pioneer of Green Hotel in East Java that implements green program.

The highest degree of the customer satisfaction was the satisfaction of the guests because of the service given by the staffs of Surabaya Plaza Hotel. The data showed that most of the respondents were satisfied over the service given by the Surabaya Plaza Hotel due to the implementation of green program and brand image that the hotel has.

Table 1. Structural Equation Modeling

\begin{tabular}{lccc}
\hline \multicolumn{1}{c}{ Criteria } & Result & Critical Value & Evaluation Model \\
\hline Chi Square & 294.87 & $<323.44$ & Fit \\
CMIN/df & 1.695 & $\leq 2.00$ & Fit \\
RMR & 0.061 & $<0.062$ & Fit \\
Probability & 0.0000 & $\geq 0.05$ & Insignificant \\
RMSEA & 0.055 & $\leq 0.08$ & Fit \\
GFI & 0.900 & $\geq 0.90$ & Fit \\
AGFI & 0.840 & $\geq 0.90$ & Marginal \\
CFI & 0.930 & $\geq 0.95$ & Marginal \\
\hline
\end{tabular}

The probability value of the model used in this research shows that the model was not fit. But the Chi Square, CMIN, RMR, RMSEA, and GFI value show that the model were fit and other instruments such as AGFI and CFI are marginally fit. Therefore, the result of this research can be used and trusted. The Structural Equation Modeling analysis provides the analysis of structural model that is used to test the relation among latent variables.

Table 2. The Relationship Among Variables

\begin{tabular}{|c|c|c|c|}
\hline \multirow{2}{*}{\multicolumn{2}{|c|}{ EXOGEN VARIABLE }} & \multicolumn{2}{|c|}{ ENDOGEN VARIABLE } \\
\hline & & Brand Image & $\begin{array}{c}\text { Customer } \\
\text { Satisfaction }\end{array}$ \\
\hline Technical & Coeficient & 0.34 & -0.21 \\
\hline Quality & $\begin{array}{l}t_{\text {value }} \\
\text { Note }\end{array}$ & $\begin{array}{l}2.73 \\
(+) \text { Significant }\end{array}$ & $\begin{array}{l}-1.60 \\
\text { (-) Not Significant }\end{array}$ \\
\hline$\overline{\text { Functional }}$ & Coeficient & 0.39 & 0.30 \\
\hline Quality & $\begin{array}{l}t_{\text {value }} \\
\text { Note }\end{array}$ & $\begin{array}{l}2.69 \\
\text { (+) Significant }\end{array}$ & $\begin{array}{l}1.90 \\
\text { (+) Significant }\end{array}$ \\
\hline $\begin{array}{l}\text { Brand } \\
\text { Image }\end{array}$ & $\begin{array}{l}\text { Coeficient } \\
t_{\text {value }} \\
\text { Note }\end{array}$ & - & $\begin{array}{l}0.73 \\
4.77 \\
(+) \text { Significant }\end{array}$ \\
\hline
\end{tabular}


1. The influence of technical quality to customer satisfaction

- Direct Influence

The coefficient of the direct influence of technical quality to customer satisfaction expressed by the path coefficient of $-0.21, t=$ -1.60. That means the relationship was not significant and the influence was negative. So that technical quality variable does not directly influence the customer satisfaction variable.

- Indirect Influence

The coefficient of indirect influence of technical quality to customer satisfaction with brand image as an intervening variable expressed by the path coefficient of $0.34 \times 0.73=0.2482$. That means the relationship was significant, and it influence indirectly through brand image. Thus, technical quality influences customer satisfaction indirectly with brand image as an intervening variable.

- Total Influence

The coefficient of the total effect of technical quality to customer satisfaction is expressed by the path coefficient of $-0.21+0.2482=$ 0.0382 . That means the relationship was significant, and the total effect was 0.0382 . So, it can be concluded that with the emergence of brand image as an intervening variable in this research model, it can improve the value of customer satisfaction.

2. The impact of Functional quality to customer satisfaction

- Direct Influence

The coefficient of the direct influence of functional quality to customer satisfaction is expressed by the path coefficient of 0.30 and $t$ $=1.99$. That means the relationship was significant, and has positive direct influence. So that the functional quality variable directly affects customer satisfaction variables.

- Indirect Influence

The coefficient of the indirect influence of functional quality to customer satisfaction with brand image as an intervening variable is expressed with path coefficient of $0.39 \times 0.73$ $=0.2847$. That means the relationship was significant, and influence indirectly through brand image. Thus functional quality indirectly affects the customer satisfaction with brand image as an intervening variable.

- Total Influence

The coefficient of total influence of functional quality to customer satisfaction is expressed by the path coefficient of $0.30+0.2847=0.5847$.
That means the relationship was significant, and has positive influence. So, it can be concluded that with the emergence of brand image as an intervening variable in this research model, it can improve the value of customer satisfaction.

\section{Hypothesis Testing}

Based on the literature review, five hypotheses were proposed, which were expected to explain the relationship among the customer perceived quality, brand image, and the customer satisfaction. The five hypothesis were tested by Structural Equation Modeling.

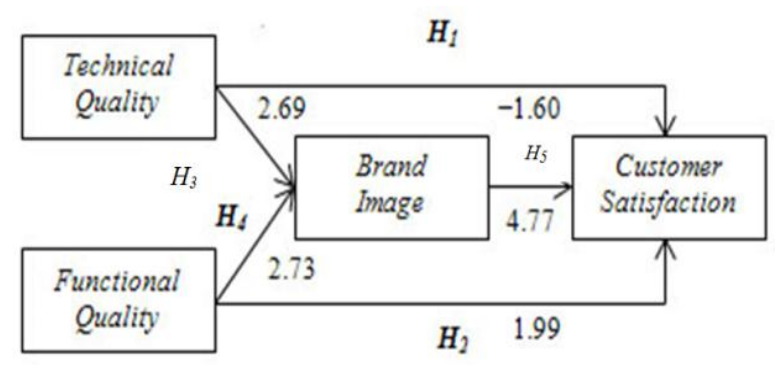

Figure 2. Hypothesis Testing

$\boldsymbol{H}_{I}$ : Suggested that technical quality of customer perceived quality directly affect the customer satisfaction. This hypothesis was rejected, due to the $t_{\text {value }}$ that was less than or equal to 1,645 , the $t_{\text {value }}$ was $-1,60$, which means the technical quality has negative impact to the customer satisfaction but it is not significant. So the relationship was not counted as affecting the customer satisfaction.

$\boldsymbol{H}_{2}$ : Suggested that functional quality of customer perceived quality directly affects the customer satisfaction. This hypothesis was accepted, because the $t_{\text {value }}=1,99$ was bigger than 1,645 , so it means significantly positive.

$\boldsymbol{H}_{3}$ : Suggested that technical quality of customer perceived quality directly affects the brand image. This hypothesis was accepted, because the $t_{\text {value }}=$ 2,69 was bigger than 1,645 , so it means significantly positive.

$\boldsymbol{H}_{4}$ : Suggested that functional quality of customer perceived quality directly affects the brand image. This hypothesis was accepted, because the $t_{\text {value }}=$ 2,73 was bigger than 1,645 , so it means significantly positive.

$\boldsymbol{H}_{5}$ : Suggested that brand image as an intervening variable between the customer perceived quality and the customer satisfaction. This hypothesis 
means the customer perceived quality affects customer satisfaction indirectly through brand image as intervening variable. This hypothesis was automatically accepted, because the $t_{\text {value }}=$ 4,77 which was bigger than 1,645 , so it means significantly positive.

\section{CONCLUSIONS AND RECOMMENDATIONS}

\section{Conclusions}

The research conducted involved 230 respondents. The number of male respondents are much more than the female respondents, 85 respondents aged 36-45 years old, 98 respondents work entrepreneur, and have monthly income more than Rp 6.000.000,00; and most of the respondents have stayed at Surabaya Plaza Hotel less than two times in the last six months.

The technical quality of customer perceived quality affects the customer satisfaction negatively but it is not significant. It means, technical quality does not give impact to the customer satisfaction directly, because the $t_{\text {value }}$ is not significant. The functional quality of customer perceived quality affects the customer satisfaction positively and significant. It means, functional quality influence the customer satisfaction directly, because the $t_{\text {value }}$ is significant. The technical quality of customer perceived quality also affects the brand image positively and significantly. It means, technical quality influences the brand image directly, because the $t_{\text {value }}$ is not significant. The functional quality of customer perceived quality also affects the brand image positively and significant. It means functional quality influences the brand image directly, because the $t_{\text {value }}$ is not significant.

From the result of this research, it can be concluded that customer perceived quality influences customer satisfaction through brand image as an intervening variable that can increase the value of the dependent variable. According Chen (2010), this was because brand image is one of the most important factors that determine customer satisfaction. That is why there is a positive relationship between brand image and customer satisfaction. Even though customer perceived quality also influences the customer satisfaction by its functional quality, but the relationship is stronger with the emergence of brand image as the intervening variable.

\section{Recommendations}

Based on the result of this research, it can be concluded that most of the variables significantly influenced customer satisfaction either directly or indirectly, except the technical quality that has no influence directly to customer satisfaction because the $t_{\text {value }}$ was not significant. That is why the author would like to make some recommendations so that those things can be maintained or developed by the company in future to achieve better result.

It is recommended for Surabaya Plaza Hotel to develop the quality of service in the hotel, and one of the most important thing is the professionalism dimension. The hotel can generate the professionalism of the staff by holding lots of training to train all the staffs. By doing so, the hotel can maintain its brand image and in the end will affect the customer satisfaction because of the good image that the brand has.

Not only developing the technical quality, Surabaya Plaza Hotel also has to develop the functional quality of the staffs in order to give more personalized service to every guest who stays in the hotel. By giving more personalized service, it means the staffs try to fulfill the variety needs of the guests who stay at the hotel to generate the satisfaction level of the guests. Furthermore, better service quality also may increase the brand image of the hotel. Since the hotel staffs are the representatives of the hotel, so every service given to the guests reflects the image of the hotel toward the guests.

From the result of this research, it can be concluded that Surabaya Plaza Hotel has succeeded in implementing the green program either to generate the brand image or even customer satisfaction. That is why it is very crucial for Surabaya Plaza Hotel to maintain and develop the green program in the daily hotel operations because this program also manages to be one of the strongest competitive advantages for the hotel to survive in the lodging industry nowadays. Furthermore, the commitment of Surabaya Plaza Hotel that has implemented the entire green program in the hotel can also give positive impact to the nature and to the world.

\section{REFERENCES}

Aaker, D. 1996. Building Strong Brands. New York: Free Press AC.

Chen, Y. S. 2010. The Drivers of Green Brand Equity: Green Brand Image, Green Satisfaction, and Green Trust. Journal of Business Ethics, 93(2): 307-319.

Gronroos, C. 2000. Service Management and Marketing: A Customer Relationship Approach. Second Edition. Singapore: John Wiley \& Sons.

Hollensen, S. 2007. Global Marketing. Fourth Edition. New Jersey: Prentice Hall. 
Kasali, R. 2009. Potensi Green Product Bergantung Stimulus. Majalah Swa Sembada, 25(10): 14 $-56$.

Kotler, P. 1997. Marketing Management: Analysis, Planning, Implementation, and Control. Ninth Edition. New Jersey: Prentice Hall.

Kotler, P., Bowen, J., \& Makens, J. 2003. Marketing for Hospitality and Tourism. Third Edition. New Jersey: Prentice Hall.
Sulastiyono, A. 1999. Manajemen Penyelenggaraan Hotel. Bandung: Alfabeta.

Supranto, J. 2006. Pengukuran Tingkat Kepuasan Pelanggan untuk Menaikkan Pangsa Pasar. Jakarta: Rineka Cipta.

Zeithaml, V. A., Bitner, M., Gremler, M., \& Dwayne, D. 2006. Services Marketing. Fourth Edition. Singapore: McGraw-Hill. 